\title{
MATERIAL PARAMETERS FOR A NUMERICAL SIMULATION OF A COMPACTION PROCESS FOR SINTERED DOUBLE-HEIGHT GEARS
}

\author{
MATERIALNI PARAMETRI ZA NUMERIČNO SIMULACIJO \\ POSTOPKA STISKANJA SINTRANIH DVOVIŠINSKIH ZOBNIKOV
}

\author{
Tomaž Verlak ${ }^{1}$, Marko Šori ${ }^{2}$, Srečko Glodež ${ }^{1}$ \\ ${ }^{1}$ University of Maribor, Faculty for Mechanical Engineering, Smetanova ulica 17, 2000 Maribor, Slovenia \\ ${ }^{2}$ University of Maribor, Faculty of Natural Sciences and Mathematics, Koroška cesta 160, 2000 Maribor, Slovenia \\ tomaz.verlak@gmail.com
}

Prejem rokopisa - received: 2014-10-16; sprejem za objavo - accepted for publication: 2014-11-06

doi:10.17222/mit.2014.262

\begin{abstract}
This paper presents the initial material parameters for the Ecka Alumix 231 aluminum-powdered metal required for a successful numerical simulation of a compaction process for sintered components with a proper software package. Experimental work was used to obtain Drucker-Prager-cap (DPC) model material parameters with the help of a Brazilian disc test and a uniaxial compression test for the linear part of the DPC model in the equivalent pressure stress/deviatoric stress (p-q) plane. The specimens used for this test were cylindrical probes (greens) that were compacted with a mechanical press and then compressed to the failure point in the axial and radial directions.

Keywords: aluminum-based powder, compaction process, Drucker-Prager cap model, numerical simulation, Ecka Alumix 231

V članku so predstavljeni začetni materialni parametri za aluminijev prah Ecka Alumix 231, ki so potrebni za uspešno izvedbo numerične simulacije stiskanja sintranih komponent s primerno programsko opremo. S porušitvenimi preizkusi in pridobljenimi eksperimentalnimi rezultati je bilo mogoče določiti potrebne parametre materiala z Drucker-Prager-jevim cap (DPC) modelom, ki določajo linearno območje DPC modela v grafu ekvivalentne tlačne obremenitve v odvisnosti od deviatorične obremenitve. Uporabljeni so bili cilindrični preizkušanci (zelenci), ki so bili stisnjeni z mehansko stiskalnico in kasneje obremenjeni do porušitve $\mathrm{v}$ osni in radialni smeri.

Ključne besede: aluminijev prah, stiskanje, Drucker-Prager-jev cap model, numerična simulacija, Ecka Alumix 231
\end{abstract}

\section{INTRODUCTION}

Sintering is a densification process of powder compacts based on the atomic diffusion of powder components. These mechanical compacts (products), especially gears (Figure 1), are widely used in numerous fields of mechanical engineering because they can be made into near-net- shaped objects with minimum or no machining after the sintering. The equipment for sintering is quite expensive and, for that reason, the sintering process required for manufacturing different, small, complex components is economical for larger production series.

The process of sintering can be divided into multiple steps, of which one of the most important is the compaction process. When a powder is being compacted with mechanically or hydraulically operated presses, the density distribution is changing.

The density magnitude and the density distribution within a component have large impacts on the mechanical properties of finished product ${ }^{1,2}$ so it is crucial that the achieved density after the compaction process is as close as possible to $100 \%$ of the theoretical density of the material and that the density distribution is uniform. To achieve a higher density and a uniform density distribution throughout the whole component after the compaction process, the press operator must have a great deal of experience to optimize the compaction parameters (the movement of the press components).

When optimizing compaction parameters based on experience, there is a great chance that damages occur to the press tools. To avoid high costs for repairing damaged tools and spending the time for optimizing the compaction parameters on a press, numerical simulations can be applied to resolve these situations. Using a numerical simulation in ABAQUS with a build-in DruckerPrager cap model, it is possible to eliminate the trial-anderror process and numerically optimize press-compaction parameters, thus saving time and money. ${ }^{2}$ The

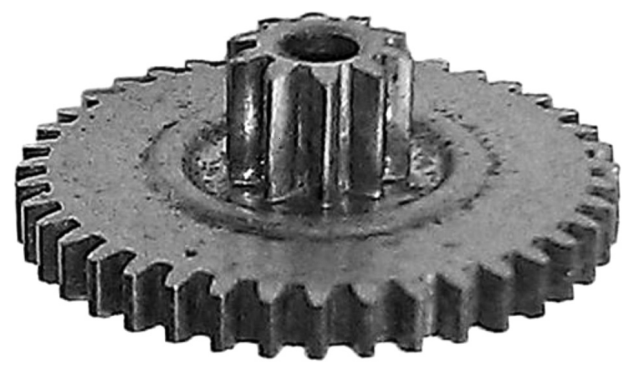

Figure 1: Double-height gear

Slika 1: Dvovišinski zobnik 


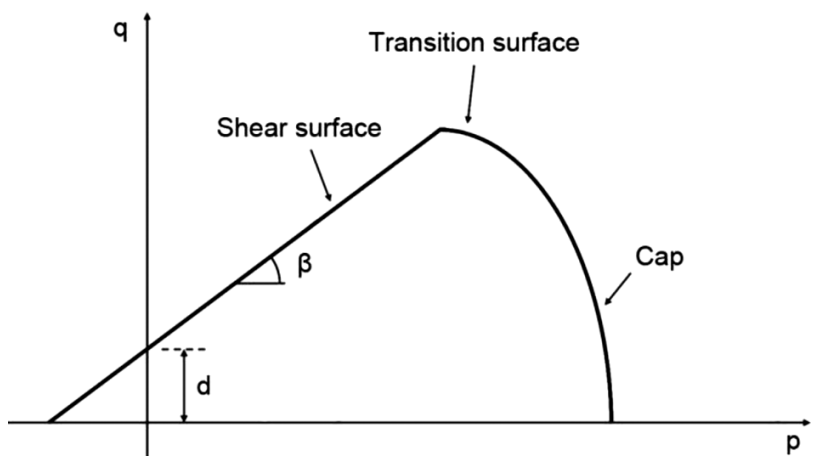

Figure 2: Drucker-Prager-cap-model chart

Slika 2: Graf Drucker-Pragerjevega cap modela

results of this kind of simulation show the local density distribution over the entire model. By optimizing the movement of the punches in a numerical simulation, the simulation can be restarted again and again with different compaction parameters and this way the results of the final density distributions can be compared. When the results of a numerical simulation are satisfactory, the compaction parameters can be transferred onto the press.

Before a numerical simulation can begin, the material parameters for the chosen metal powder must be known. These parameters are hard to come by or, in some cases, they do not even exist, which is specially the case with most aluminum powders. ${ }^{3}$ To obtain the material parameters for a successful simulation, suitable tests must be done. These tests include a Brazilian disc test, a uniaxial compression test and a triaxial compression test. With these tests, it is possible to obtain the parameters that are needed for drawing a Drucker-Prager-cap-model chart and start a numerical simulation. The Drucker-Pragercap-model chart, shown in Figure 2, is presented with the equivalent pressure stress/deviatoric stress (p-q) plane. It consists of three surfaces. ${ }^{4,5}$ The first is the shear surface, the second is the transition surface and the third is the cap surface. This paper focuses on gathering the Drucker-Prager-cap-model parameters for the linear part, presented with the shear surface, and the tests required to

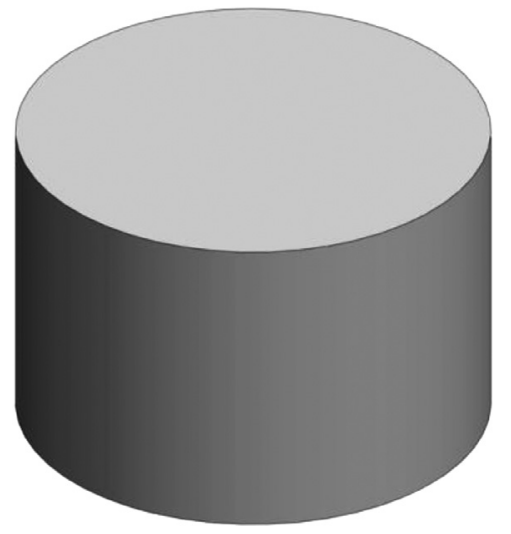

Figure 3: Specimen - a cylindrical disc Slika 3: Vzorec - cilindrični plošček gather proper information include a Brazilian disc test and a uniaxial compression test.

\section{EXPERIMENTAL WORK}

For the experimental work, the Ecka Alumix 231 aluminum powder was used. The basic powder specifications can be found in Table 1 where $\rho_{\mathrm{A}}$ is the apparent density, $\rho_{\mathrm{G}}$ is the green density and $\sigma_{\mathrm{CP}}$ is the recommended compaction pressure. The testing can be divided into two parts. The first part involves the preparation of the samples and the second part involves the testing of the samples to the failure point and the reading of the failure-point load. The specimens used in this experimental work ware cylindrical discs (Figure 3) prepared with a DORST TPA 45 mechanical press (Figure 4) that is capable of a compaction force of $440 \mathrm{kN}$. A total of 24 samples were prepared. Each compacted specimen was measured and the values are presented in Table 2 where $D$ is the diameter of a specimen, $L$ is the height of a specimen, $m$ is the mass and $\rho_{\mathrm{G}}$ is the green density of a specimen.

Table 1: Basic properties of aluminum powder Ecka Alumix 231 Tabela 1: Osnovne lastnosti aluminijevega prahu Ecka Alumix 231

\begin{tabular}{|c|c|c|c|c|c|}
\hline \multicolumn{3}{|c|}{ Physical characteristics } & \multicolumn{3}{c|}{ Chemical compositions, } \\
& & \multicolumn{3}{c|}{$\%$} \\
\hline$\rho_{\mathrm{A}} /\left(\mathrm{g} / \mathrm{cm}^{3}\right)$ & $\rho_{\mathrm{G}} /\left(\mathrm{g} / \mathrm{cm}^{3}\right)$ & $\sigma_{\mathrm{CP}} / \mathrm{MPa}$ & $\mathrm{Si}$ & $\mathrm{Cu}$ & $\mathrm{Mg}$ \\
\hline $1.05-1.25$ & 2.56 & 620 & $14-16$ & $2.4-2.8$ & $0.5-0.8$ \\
\hline
\end{tabular}

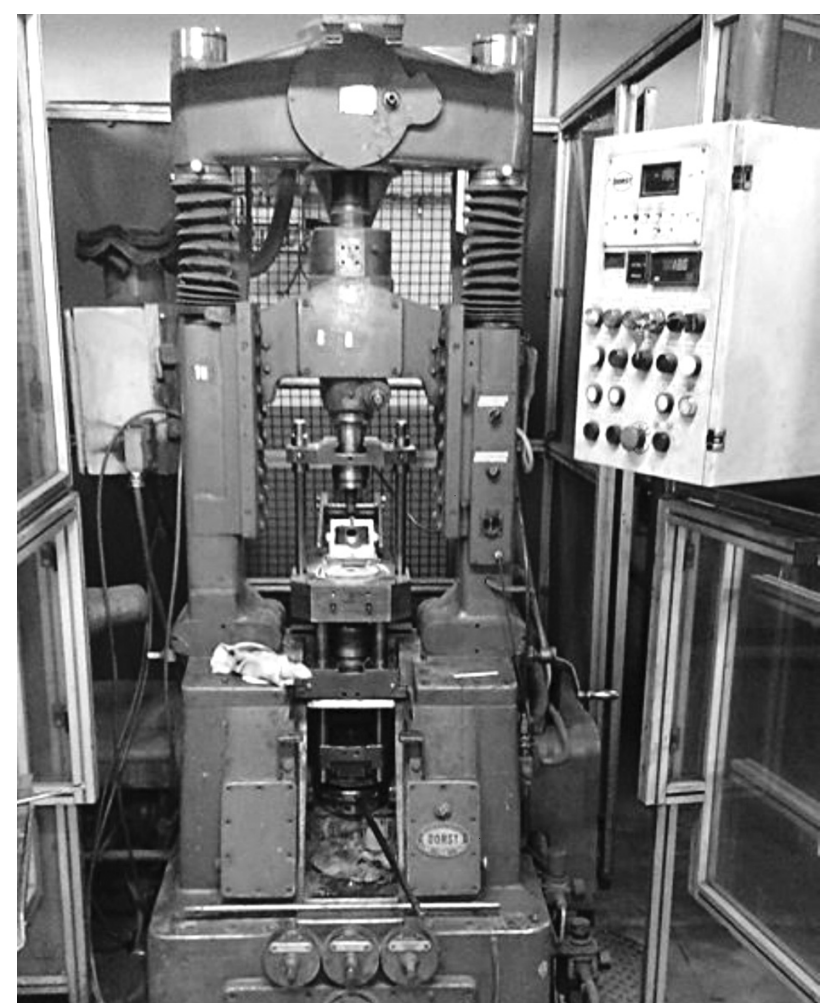

Figure 4: Dorst TPA 45 mechanical press

Slika 4: Mehanska stiskalnica Dorst TPA 45 


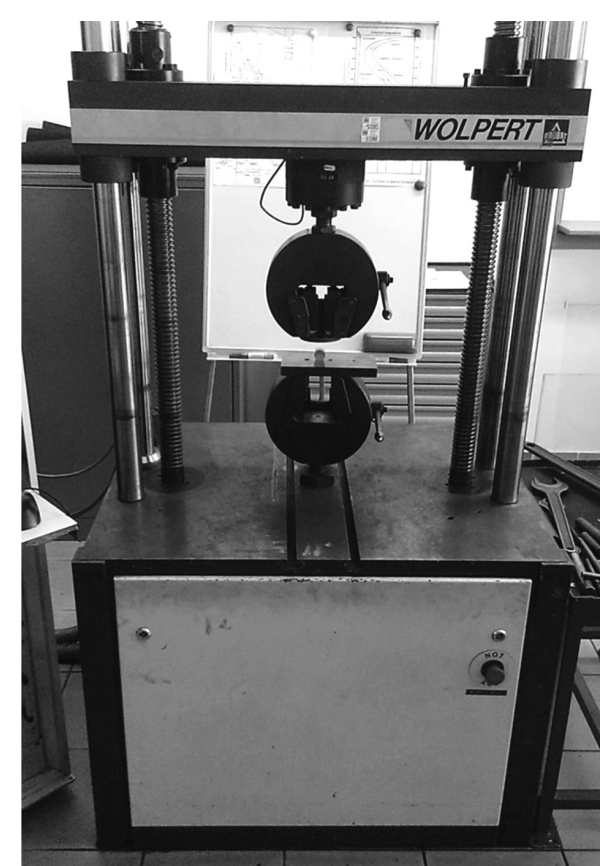

Figure 5: Wolpert TZZ 100 material-testing machine Slika 5: Stroj za preizkušanje materialov Wolpert TZZ 100

Table 2: Average numerical values of specimens Tabela 2: Povprečne numerične vrednosti vzorcev

\begin{tabular}{|c|c|c|c|c|}
\hline Specimens & $D / \mathrm{mm}$ & $L / \mathrm{mm}$ & $\mathrm{m} / \mathrm{g}$ & $\rho_{\mathrm{G}} /\left(\mathrm{g} / \mathrm{cm}^{3}\right)$ \\
\hline $1-6$ & 24.15 & 16.19 & 18.73 & 2.53 \\
\hline $7-12$ & 24.15 & 16.21 & 18.79 & 2.53 \\
\hline $13-18$ & 24.14 & 16.27 & 17.28 & 2.32 \\
\hline $19-24$ & 24.15 & 16.28 & 17.30 & 2.32 \\
\hline
\end{tabular}

For the second part of the experimental work, specimens were tested to the failure point with a WOLPERT TZZ 100 material-testing machine (Figure 5) that is capable of measuring compression and tension forces of up to $100 \mathrm{kN}$. The specimens were placed between two metal plates and then tested. ${ }^{6} 12$ cylindrical discs were

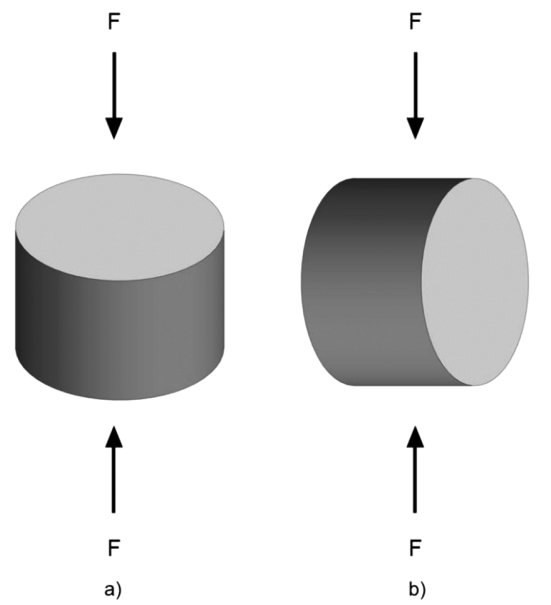

Figure 6: a) Axial and b) radial load directions Slika 6: a) Osna in b) radialna obremenitev

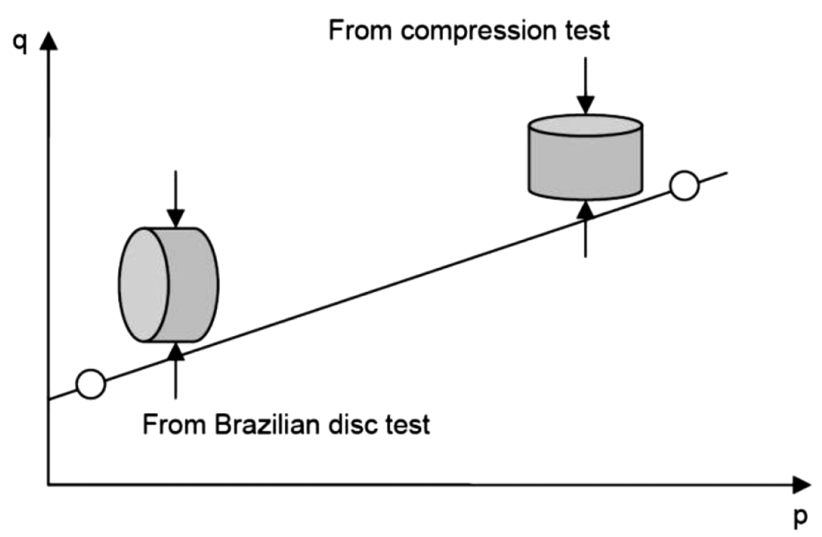

Figure 7: Linear part of the Drucker-Prager-cap model Slika 7: Linearni del Drucker-Pragerjevega cap modela

tested to the failure point in the axial direction (Figure 6a) using a testing speed of $5 \mathrm{~mm} / \mathrm{min}$ and another 12 in the radial direction (Figure $6 \mathbf{b}$ ) using a testing speed of $2.5 \mathrm{~mm} / \mathrm{min}$.

\section{RESULTS AND DISCUSSION}

In order to obtain the linear part of the DruckerPrager-cap model (Figure 7) parameters $p$ and $q$ for the compression test and Brazilian disc test must be calculated from the gathered data, where $p$ is the hydrostaticpressure stress and $q$ is the deviatoric stress. For the compression test, parameter $p$ can be calculated using Equation (1) and parameter $q$ is calculated using Equation (2). For the Brazilian disc test, parameter $p$ can be calculated using Equation (3), and parameter $q$ is calculated using Equation (4):

$$
\begin{gathered}
p=\frac{\sigma_{\mathrm{c}}}{3} \\
q=\sigma_{\mathrm{c}} \\
p=\frac{2 \sigma_{\mathrm{t}}}{3}
\end{gathered}
$$

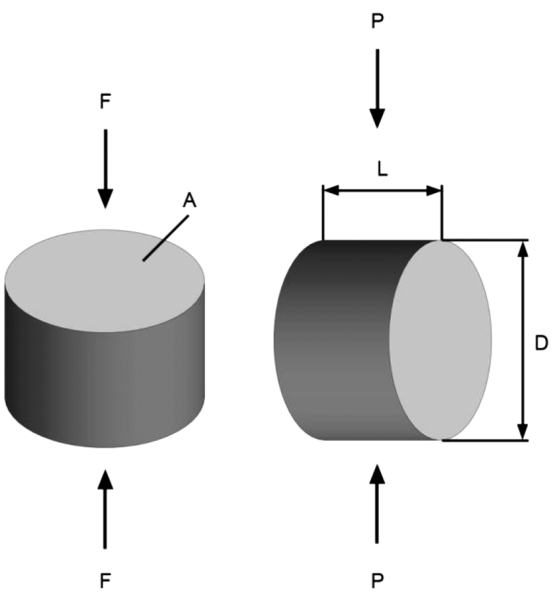

Figure 8: Parameters for calculation

Slika 8: Parametri za preračun 


$$
q=\sqrt{13} \sigma_{\mathrm{t}}
$$

where $\sigma_{\mathrm{c}}$ represents the compression strength expressed with Equation (5) and $\sigma_{\mathrm{t}}$ represents the splitting tensile strength expressed with Equation (6):

$$
\begin{gathered}
\sigma_{\mathrm{c}}=\frac{F}{A} \\
\sigma_{\mathrm{t}}=\frac{2 P}{\pi L D}
\end{gathered}
$$

where $F$ is the maximum load applied during the uniaxial compression test, $A$ is the surface area of a specimen, $P$ is the maximum load applied during the Brazilian disc test, $L$ is the thickness of a specimen and $D$ is the diameter of a specimen. All the parameters mentioned above are presented in Figure 8. Table 3 presents the average values gathered during the experimental work, where $F$ is the maximum load applied in the axial direction and $P$ is the maximum load applied in the radial direction. As expected, the values of the maximum load applied during the Brazilian disc test are smaller because of a grater notch factor and a smaller surface. With the help of Equations (1) to (6) and the added trend line, the linear part of the Drucker-Pragercap model was plotted and it is presented in Figure 9.

Table 3: Average values of applied loads

Tabela 3: Povprečne vrednosti uporabljene sile

\begin{tabular}{|c|c|c|c|}
\hline Specimens & Load direction & $F / \mathrm{N}$ & $P / \mathrm{N}$ \\
\hline $1-6$ & axial & 77145 & $/$ \\
\hline $7-12$ & radial & $/$ & 8405 \\
\hline $13-18$ & axial & 64394 & $/$ \\
\hline $19-24$ & radial & $/$ & 4275 \\
\hline
\end{tabular}

Using Microsoft Excel and its feature "display equation", the equation for the linear part of the Drucker-Prager-cap model of the Ecka Alumix 231 aluminumpowder metal can be displayed (Equation (7)):

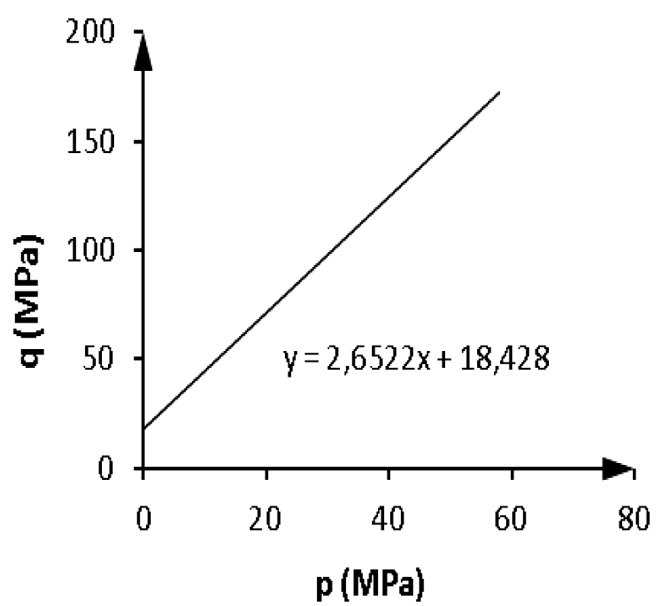

Figure 9: Linear part of the Drucker-Prager-cap model for powder Ecka Alumix 231

Slika 9: Linearni del Drucker-Prager-jevega cap modela za prah Ecka Alumix 231

$$
y=2.65 x+18.43
$$

In order to successfully complete the numerical simulation in ABAQUS, parameters $d$ and $\beta$ must be obtained. ${ }^{2,7}$ Parameter $d$ represents the material cohesion and parameter $\beta$ represents the angle of friction. Both of these parameters can be obtained from Equation (7). Parameter $d$ is the point on the p-q plane where the line intersects the $y$ axis (Figure 2) and it has a value of 18.43 MPa. Parameter $\beta$ represents the slope of the linear part (Figure 2) and can be calculated using Equation (8):

$$
\beta=\tan ^{-1} 2.65
$$

Using Equation (8), the angle of friction was calculated, having a value of $69^{\circ}$.

\section{CONCLUSIONS}

Both the Brazilian disc test and the compression test are very popular testing methods for gathering material data for the linear part of a Drucker-Prager-cap model. ${ }^{2}$ They are both inexpensive methods because individual specimens do not have to have exactly the same dimensions and the testing equipment is widely accessible. Dimensions are then taken into account with the use of appropriate equations. Lower-density specimens result in a lower applied failure load due to a lower diffusion of dust particles and a greater notch factor. On the other hand, higher-density specimens result in a higher applied failure load. The present study shows that there is a linear relationship for the specimens with different densities and that the specimens with higher densities are much more resistant to higher loads.

\section{REFERENCES}

${ }^{1}$ S. G. Selig, D. A. Doman, A Review of Finite Element Simulations of Metal Powder Die Compaction, Journal of Machinery Manufacturing and Automation, 3 (2014) 2, 32-40

${ }^{2}$ C. Lu, Determination of Cap Model Parameters Using Numerical Optimization Method for Powder Compaction, Dissertations, Marquette University, 2009

${ }^{3}$ L. H. Han, J. A. Elliott, A. C. Bentham, A. Mills, G. E. Amidon, B. C. Hancock, A modified Drucker-Prager Cap model for die compaction simulation of pharmaceutical powders, International Journal of Solids and Structures, 45 (2008), 3088-3106, doi:10.1016/j.ijsolstr. 2008.01.024

${ }^{4}$ ABAQUS, ABAQUS 6.11 Theory Manual, Dessault Systems, 2011

${ }^{5}$ H. Diarra, V. Mazel, A. Boillon, L. Rehault, V. Busignies, S. Bureau, P. Tchoreloff, Finite Element Method (FEM) modeling of the powder compaction of cosmetic products: Comparison between simulated and experimental results, Powder Technology, 224 (2012), 233-240, doi:10.1016/j.powtec.2012.02.058

${ }^{6}$ Y. Yu, J. Yin, Z. Zhong, Shape effects in the Brazilian tensile strength test and 3D FEM correction, International Journal of Rock Mechanics \& Mining Sciences, 43 (2006), 623-627, doi:10.1016/ j.ijrmms.2005.09.005

${ }^{7}$ M. Šori, T. Verlak, S. Glodež, Numerical simulation of powder metal compaction with Drucker-Prager cap model in a multi height component, Euro PM2013 congress \& exhibition, Vol. 2, Gothenburg, Sweden, 7-11 